\title{
Facts About Fire
}

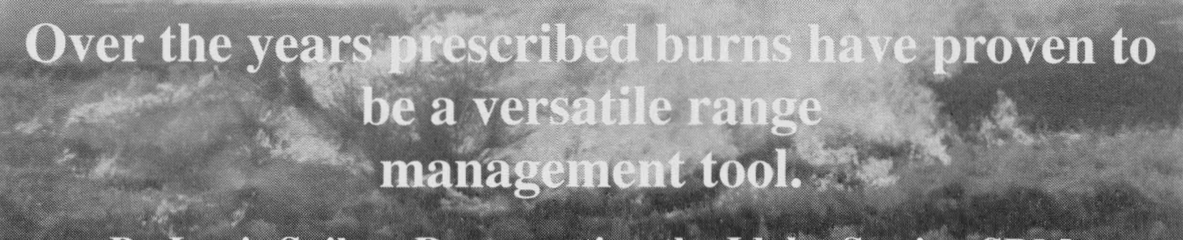

By Louis Spiker, Representing the Idaho Section SRM

Despite the devastating effects a wildfire outbreak can have on homes and people today, prescribed burns are a well-planned program aimed at range improvement through the use of fire.

Historically, ecosystem integrity was maintained by fire. Lightning caused fires that burned every 3 to 28 years. Nearly one-third of these fires were large and usually preceded by above average precipitation and optimum growth conditions. These fires burned until they ran out of fuel and in doing so they controlled the densities of Artemisia tridentata (big sagebrush) and Juniperus occidentalis (western juniper).

Starting in 1924 with the Clark McNary Act the federal government enacted a policy of fire suppression. This has been a factor in the increasing density of big sagebrush and western juniper. But, fire has now come full circle. It is being used to manage ecosystem integrity, now introduced in the form of prescribed burns.

Prescribed burns are a versatile range management tool. One of the benefits of introducing fire into an area with prescribed burns is an increase in the amount of available forage. In areas of dense sagebrush only half the palatable grasses and weeds are likely to be available to livestock. Prescribed burns can be utilized to improve the grazing capacity in this type of area. Studies have shown up to a sixty nine percent increase in grazing capacity as a result of prescribed burns. Any increase in forage available to livestock and wildlife is an improvement.

Prescribed fires also reduce the number of undesirable annual grasses and forbs that compete with more desirable perennials. Fire allows the perennial grasses to grow rapidly with out the extra competition. Prescribed burning is used to stimulate an increase of climax plant species and helps maintain low growth desirable brush while stimulating forb production. This improves the quality of the forage available to livestock and wildlife.

\section{Benefits Soil, Water And Wildlife, Too}

Another benefit of using fire as a range management tool is an increase in soil moisture and ground water. The increased soil moisture gives the more desirable perennial grasses better growing conditions. Where water is available to livestock is an indicator of whether an area may be cost effectively grazed. To graze livestock in the drier months of the year, producers must either have a natural supply of water or they must haul water to their livestock. When dense populations of western juniper and big sagebrush are burned more water becomes available, and often fills up creeks that serve as a water source for livestock and wildlife.

Wildlife also benefit from prescribed burns. Upland game birds like the sage grouse benefit from the habitat diversity resulting from a prescribed burn. Birds and other small game have more access to edge habitat where they can easily find cover and food. Large game such as mule deer and antelope also benefit from the increase in more usable forage.

Prescribed burns are a well-planned process. Each prescribed burn must include a fire use plan. The area's terrain and weather must all be researched to find a safe burn window. Land management objectives and treatment constraints are considered.
Success of the prescribed burn is dependent on this process. Large areas of land need to have a long-term plan developed. The area should be divided into sections that will be burned in a 15 to 20 year rotation.

Prescribed burns are also a cost-effective management practice. The Idaho State Department of Lands has been able to conduct prescribed burns of western juniper and big sagebrush in areas in southwestern Idaho from $\$ 4.06 /$ acre to $\$ 2.36 /$ acre. Using a herbicide such as "Tordon" to treat an area would cost approximately $\$ 25 /$ acre just for the herbicide. This is a significant savings. Large prescribed burns are more economical than smaller burns, because even though the burn is smaller it still requires the same amount of preparation.

Prescribed burns have proven themselves to be a valuable range resource management tool. They are able to improve the quality of the forage available to livestock and wildlife. They are a cost-effective way to control western juniper and big sagebrush density. They are a management tool that benefits wildlife. Even though prescribed burns are not suited for all locations they are an excellent range management tool that have the ability to leave areas that were once choked with juniper lush with forage.

This was the third place paper in the High School Youth Forum presentation competition at the 2000 SRM Annual Meeting at Boise, Idaho.

\section{References}

"Fire History and Western Juniper encroachment in sage-brush steppe." Richard F. Miller and Jeffery A. Rose. J. Range Management 52:550-559 November 1999.

"Sagebrush Burning...Good and Bad." Joseph F. Pechanec and George Stewart. USDA, 1948.

"Cattle and Fire-Important Tools Benefiting Wildlife." Joe Franklin and Rex Brand, Rangelands 13(4) August 1991. 